\title{
Early detection of stage A prostate carcinoma: Combined use of prostate- specific antigen and transrectal ultrasonography
}

\author{
ROBERT L. FIORELLI, DO \\ ROBERT L. KLAUS, MD \\ SAMUEL J. MANFREY, DO \\ LAURENCE H. BELKOFF, DO \\ LEONARD H. FINKELSTEIN, DO
}

We prospectively studied 103 men who had normal results on digital prostate examinations but had bladder outlet obstruction secondary to prostatic hypertrophy and needed transurethral prostatectomy. All men underwent a preoperative transrectal ultrasonographic examination of the prostate and prostatespecific antigen (PSA) level determination. A total of 30 cancers were ultimately detected, $22(73 \%)$ of which were detected preoperatively by either an abnormal ultrasonogram or elevated PSA levels (or both). Eight of these men were spared transurethral prostatectomy and had definitive treatment based on transrectal biopsy and appropriate staging evaluation. For PSA and ultrasonography combined, the sensitivities and negative predictive values for cancer $(92 \%$ and $94 \%$, respectively) were superior to the specificities and positive predictive values $(71 \%$ and $64 \%$, respectively). The combined use of both studies is recommended to rule out cancer in candidates for prostatectomy

From the Departments of Urology at Osteopathic Medical Center of Philadelphia and Albert Einstein Medical Center, Philadelphia.

Reprint requests to Robert L. Fiorelli, DO, 1010 E Mountain Dr, Suite 306, Wilkes-Barre, PA 18702.

but not to routinely screen the general male population older than 40 years.

(Key words: Prostate, prostate carcinoma, prostate-specific antigen, transrectal ultrasonography of the prostate)

Prostate cancer is the most common tumor in men and is the third leading cause of cancer death in American men. ${ }^{1}$ Historically, the diagnosis has relied on palpation of an abnormal gland or unexpected discovery after simple prostatectomy (suprapubic or transurethral) for supposedly benign prostatic hypertrophy. This latter category has represented stage A prostate cancer. In 1965 , Denton and coauthors $^{2}$ suggested that approximately $20 \%$ of prostates removed for benign disease would have carcinoma. If one considers the many transurethral prostatectomies performed in the United States alone, 20\% represents a significant number of newly diagnosed malignancies.

Since the development of transrectal ultrasonography, Lee and associate ${ }^{3-5}$ have implied a possible role for this modality in detecting nonpalpable prostate cancer. Others have relegated its use to staging local disease and monitoring responses to various forms of treatments. ${ }^{6}$ The same controversies appear to exist for prostate-specific antigen (PSA) deter- 
mination. Stamey and colleagues ${ }^{7,8}$ have very nicely documented the role of PSA determination in follow-up to treatment in many situations. However, PSA alone may not be a highly reliable marker to detect prostate cancer, because elevations can occur with prostatitis and even enlarged benign glands.

The availability of transrectal ultrasonography and PSA has prompted others to study their usefulness in detecting nonpalpable prostate cancer. $4,9,10$ These studies base the accuracy of both modalities on tissue obtained merely from transrectal or transperineal biopsy. None have used the final tissue diagnosis of prostatectomy specimens in patients with glands normal to palpation. As a result, we have tried to resolve some of the controversies by combining PSA values with transrectal ultrasonography results before prostatectomy and clinically correlate these data with the presence or absence of carcinoma not only in the biopsy tissue but also in the prostatectomy specimens. In so doing, we believe that a more accurate assessment of the specificity and sensitivity of these two modalities in the early detection of stage A prostate cancer can be made.

\section{Materials and methods}

Participants in this prospective study were selected from more than 500 eligible patients. The 103 men chosen, who were between the ages of 54 and 89 (mean, 71) years, were those whose prostates were judged normal on digital examination by at least two of us. All men were also candidates for transurethral resection of the prostate (TURP) because of outlet obstruction secondary to prostatic hypertrophy. These conclusions were decided by history, urine flowmetry, postvoid residual volume determinations, and cystoscopy in selected patients. Others were excluded because of urinary tract infection, prostates suspected to be abnormal, or clinical evidence of prostatitis.

Before digital rectal examination or urethral manipulation, a serum PSA level was obtained. The PSA value was determined by the Tandem- $R$ assay (Hybritech Inc, San Diego, Calif). A urinalysis and digital rectal examination were subsequently performed.

Once the PSA results were reported, the patients were scheduled to undergo transrectal ultrasonographic examinations of the prostate. All studies were performed on an outpatient basis. The men were instructed to take a Fleet enema the night before the examination.

Ultrasonography was performed in real time with the Brüel and Kjaer type 1846 scanner and independent transaxial and sagittal probes. Transaxial scanning was done with a type $18507 \mathrm{MHz}$ probe (focal range 2 to $5 \mathrm{~cm}, 90$-degree angle) beginning at the seminal vesicles and proceeding to the prostatic apex. Sagittal scanning was performed with a type 8537 section scanning probe. The prostate was first viewed in the midsagittal plane; thereafter, each side was viewed independently with and without magnification on the ultrasound monitor.

If the PSA value was elevated or if the ultrasonogram was suggestive of carcinoma (hypoechoic or mixed), the patient underwent a transrectal biopsy of the prostate.

The ultrasound-guided biopsy was done with a needle guide attached to the sagittal probe between two condoms. Prostatic core biopsy specimens were obtained with an 18-gauge Biopty needle (Bard Urological Division, C. R. Bard, Inc., Covington, $\mathrm{Ga}$ ) with the assistance of a Biopty gun (Uppsala, Sweden). When the ultrasonogram showed an abnormality, the biopsy was performed in the region suspected to be abnormal. If only the PSA level was elevated ( $>4 \mathrm{ng} / \mathrm{mL}$ ), two random biopsy specimens were taken from each side of the gland. Before the biopsy, patients received $500 \mathrm{mg}$ of ciprofloxacin orally and were instructed to take two additional doses at 12-hour intervals after biopsy.

Patients whose biopsy results indicated malignancy underwent staging evaluation (bone scan, computed tomography, magnetic resonance imaging of the pelvis). Treatment was then based on the results of this evaluation. All other patients underwent transurethral prostatectomies as planned using the usual modern fiberoptic resection equipment. In cases where carcinoma was detected on TURP specimens and missed on biopsy, the patients were staged and treated accordingly.

The staging system for ultrasound-diagnosed malignancies was the modification of the Whitmore system proposed by Lee and co-worker. ${ }^{4}$ Conventional staging of TURP specimens was done by the Jewitt-Whitmore system. ${ }^{11}$

The equations used to calculate sensitivity, specificity, positive predictive value, and negative predictive value,${ }^{4}$ as well as accuracy were the following:

Sensitivity $=$ true-positive results/(true-positive results + false-negative results).

Specificity $=$ true-negative results/(true-negative results + false-positive results). 
Table 1

Summary of All 30 Cancers Discovered

\begin{tabular}{|c|c|c|c|c|}
\hline \multirow[b]{2}{*}{$\begin{array}{l}\text { Stage of } \\
\text { carcinoma* }\end{array}$} & \multicolumn{2}{|c|}{ Patients } & \multirow[b]{2}{*}{$\begin{array}{c}\mathrm{PSA} \dagger \text { range }, \\
\mathrm{ng} / \mathrm{mL}\end{array}$} & \multirow{2}{*}{$\begin{array}{c}\text { Gleason } \\
\text { score } \\
\text { range }\end{array}$} \\
\hline & No. & $\begin{array}{c}\text { Age } \\
\text { range, yr }\end{array}$ & & \\
\hline $\mathrm{A} 1$ & 9 & 66 to 85 & 1.9 to $\quad 7.9$ & 4 to 6 \\
\hline A2 & 8 & 62 to 80 & 2.9 to 106.0 & 4 to 8 \\
\hline $\mathrm{uA}$ & 7 & 66 to 79 & 6.4 to $\quad 50.0$ & 4 to 7 \\
\hline D1 & 4 & 68 to 83 & 21.2 to 125.0 & 5 to 9 \\
\hline D2 & 2 & 79 to 81 & 54.0 to 4400.0 & 7 to 9 \\
\hline
\end{tabular}

\begin{tabular}{|cccc|}
\hline \multicolumn{4}{|c|}{$\begin{array}{c}\text { Table 2 } \\
\text { Ultrasound Features of All Carcinomas }(\mathbf{n}=\mathbf{3 0})\end{array}$} \\
\hline $\begin{array}{c}\text { Stage of } \\
\text { carcinoma* }\end{array}$ & Hypoechoic & Mixed & Isoechoic \\
\hline A1 & 5 & 2 & 2 \\
A2 & 6 & 0 & 2 \\
uA & 6 & 1 & 0 \\
D1 & 3 & 1 & 0 \\
D2 & 1 & 1 & 0 \\
\hline "Jewitt-Whitmore ${ }^{11}$ and Lee ${ }^{4}$ staging systems. & & \\
\hline
\end{tabular}

tal biopsy in 22 men. Ultimately, 30 cancers were detected in the biopsy and prostatectomy specimens. The cancer stages and ranges of patient ages, PSA values, and Gleason scores are summarized in Table 1 . In this group, there were only four patients with normal PSA values (three stage $\mathrm{A} 1$ and one stage A2). No direct

Positive predictive value $=$ true-positive results/ (true-positive results + false-positive results).

Negative predictive value $=$ true-negative results/(true-negative results + false-negative results).

Accuracy $=$ (true-positive results + true-negative results/(true-positive results + true-negative results + false-positive results + false-negative results).

All data were then calculated as percentages by multiplying each score by 100 .

\section{Results}

A total of $71(68.9 \%)$ patients underwent a transrectal biopsy because of an abnormal ultrasonogram or elevated PSA value (or both). Cancer was detected preoperatively by transrec- correlation existed between stage of cancer, Gleason score, and PSA values. The widest variation in PSA values $(2.9 \mathrm{ng} / \mathrm{ml}$ to $106 \mathrm{ng} / \mathrm{mL})$ seemed to be in the stage A2 carcinomas rather than stage A1 because none of the patients with stage A1 disease had PSA values above $8 \mathrm{ng} / \mathrm{mL}$.

The ultrasonographic features of these cancers are depicted according to stage in Table 2. Only four (13\%) malignant lesions were isoechoic (two stage A1 and two stage A2). Five (17\%) had mixed echoic patterns, and the remaining $21(70 \%)$ were hypoechoic. In three patients with purely hyperechoic glands considered normal, no cancer was detected on TURP. 


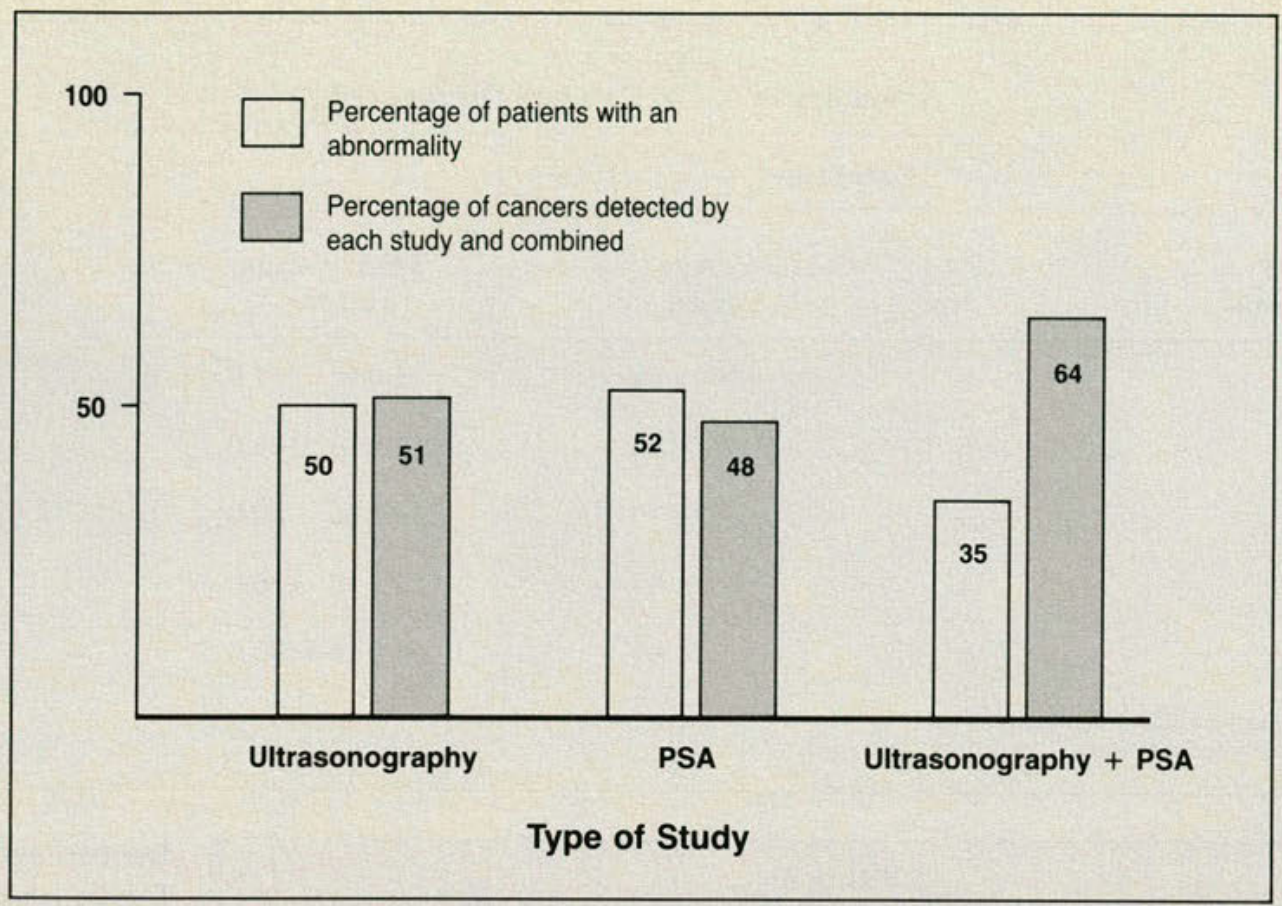

Figure. Percentage of patients with an abnormality on ultrasonographic study or prostatespecific antigen assay and percentage of cancers detected by each test alone and combined.

\begin{tabular}{|c|c|c|}
\hline \multicolumn{3}{|c|}{$\begin{array}{c}\text { Table } 3 \\
\text { Treatment and Stage of Nine Carcinomas } \\
\text { Diagnosed by Transrectal Biopsy } \\
\text { (No Transurethal Resection } \\
\text { of Prostate Performed) }\end{array}$} \\
\hline $\begin{array}{l}\text { Age of } \\
\text { patient }\end{array}$ & $\begin{array}{l}\text { Stage of } \\
\text { carcinoma* }\end{array}$ & Treatment \\
\hline 67 & $\mathrm{uA}$ & Surveillance \\
\hline 62 & $\mathrm{uA}$ & $\begin{array}{l}\text { External beam radiation } \\
\text { therapy }\end{array}$ \\
\hline 70 & $\mathrm{uA}$ & Radical prostatectomy \\
\hline 79 & $\mathrm{uA}$ & $\begin{array}{l}\text { External beam radiation } \\
\text { therapy }\end{array}$ \\
\hline 78 & $\mathrm{uA}$ & $\begin{array}{l}\text { External beam radiation } \\
\text { therapy }\end{array}$ \\
\hline 75 & $\mathrm{uA}$ & $\begin{array}{l}\text { External beam radiation } \\
\text { therapy }\end{array}$ \\
\hline 84 & $\mathrm{uA}$ & $\begin{array}{l}\text { External beam radiation } \\
\text { therapy }\end{array}$ \\
\hline 79 & D2 & Orchiectomy \\
\hline 81 & D2 & Orchiectomy + flutamide \\
\hline
\end{tabular}

Overall, 51 patients had ultrasonograms showing abnormality, and 26 of these had cancer. Of the 54 patients with elevated PSA values, 26 had cancer. Only 36 patients had both an ultrasonogram showing abnormality and an elevated PSA value; of these, 23 ultimately had cancer detected. The relative yield of each test alone and combined are graphically illustrated in the Figure.

Of these 36 patients, nine could have their cancer staged and be treated on the basis of biopsy results, thereby avoiding TURP. Only one of these nine patients refused treatment and TURP after his staging evaluation. Table 3 demonstrates the stages and treatment offered to these nine patients who did not require immediate TURP for obstructive symptoms. The other cancer patients who were subjected to TURP subsequently underwent staging and were treated accordingly (surveillance or external beam radiation therapy).

A total of 34 patients had ultrasonograms showing normal results (isoechoic) and normal PSA values. Only two $(6 \%)$ of these patients had cancer noted on TURP (stage A1). The overall true- and false-positive and true- and falsenegative results are listed in Table 4 . These 
results are based on biopsy results alone. Table 5 reviews the true- and false-positive and true- and false-negative results for transrectal ultrasonography and PSA alone and combined based on tissue results from the needle biopsy and TURP specimens.

The sensitivities, specificities, positive and negative predictive values, and accuracy of ultrasonography and PSA values alone and in combination were then calculated and are listed in Table 6. Calculations were performed on the basis of values reported in Tables 4 and 5 .

The patients had no major complications from the transrectal needle biopsies. No urinary tract infections nor urosepsis developed. Only 15 patients reported having transient hematuria or rectal bleeding, which resolved spontaneously within 24 hours. Two patients had hemospermia, which was also self-limited in each case.

As for the patients who were treated for cancer on the basis of biopsy, primary fibrinolysis developed in one patient after orchiectomy for treatment of stage D2 cancer, which was discovered by transrectal ultrasonographic examination and elevated PSA $(4400 \mathrm{ng} / \mathrm{mL})$. Scrotal hematoma also developed. The patient was treated conservatively with aminocaproic acid (to reverse the coagulopathy), scrotal elevation,
Table 4

Correlation of All True- and False-Positive and True- and False-Negative Values for

Prostate-Specific Antigen and Ultrasound Study Results With Pathologic Results From Needle Biopsy Specimens Alone $(n=71)$

\begin{tabular}{|c|c|c|}
\hline Value & $\begin{array}{l}\text { Prostate- } \\
\text { specific } \\
\text { antigen }\end{array}$ & $\begin{array}{l}\text { Ultrasound } \\
\text { Study }\end{array}$ \\
\hline True-positive* & 21 & 22 \\
\hline True-negative $\dagger$ & 16 & 19 \\
\hline False-positive $\ddagger$ & 33 & 29 \\
\hline False-negatives§ & 1 & 1 \\
\hline \multicolumn{3}{|c|}{$\begin{array}{l}\text { *Abnormal study with cancer detected. } \\
\text { †Normal study with no cancer detected. } \\
\ddagger \text { Abnormal study with no cancer detected. } \\
\$ \text { Normal study with cancer detected. }\end{array}$} \\
\hline
\end{tabular}

and ice. The coagulopathy and hematoma resolved within 10 days.

To date, no complications from the TURP, radiation therapy, and radical prostatectomy have been reported.

\section{Discussion}

The incidental discovery of a small amount of cancer in the prostate after suprapubic or transurethral resection (stage A1) was once considered insignificant. Follow-up usually in-

\begin{tabular}{|c|c|c|c|}
\hline \multicolumn{4}{|c|}{$\begin{array}{l}\text { Table } 5 \\
\text { Correlation of All True- and False-Positive and True- and False-Negative } \\
\text { Values for Prostate-Specific Antigen and Ultrasound Study } \\
\text { (or Both) With Pathologic Results From Transurethral Resection of the } \\
\text { Prostate and Needle Biopsy Specimens Combined }\end{array}$} \\
\hline Value & $\begin{array}{l}\text { Prostate- } \\
\text { specific } \\
\text { antigen } \\
(\mathbf{n}=103)\end{array}$ & $\begin{array}{l}\text { Ultrasound } \\
\text { study } \\
(\mathbf{n}=\mathbf{1 0 3})\end{array}$ & $\begin{array}{c}\text { Combined } \\
\text { modalities } \\
(n=70)\end{array}$ \\
\hline True-positive* & 26 & 26 & 23 \\
\hline True-negative $\dagger$ & 45 & 48 & 32 \\
\hline False-positive $\ddagger$ & 28 & 25 & 13 \\
\hline False-negatives§ & 4 & 4 & 2 \\
\hline \multicolumn{4}{|c|}{$\begin{array}{l}\text { *Abnormal study with cancer detected. } \\
\text { †Normal study with no cancer detected. } \\
\text { †Abnormal study with no cancer detected. } \\
\$ \text { Normal study with cancer detected. }\end{array}$} \\
\hline
\end{tabular}


Table 6

Calculated Sensitivities, Specificities, Positive and Negative Predictive Values, and Accuracy for Biopsy Specimens Alone (B) and Final Tissue from Transurethral Resection of Prostate and Biopsy (TURP + B)*

\begin{tabular}{|c|c|c|c|c|c|}
\hline \multirow[b]{2}{*}{ Value } & \multicolumn{2}{|c|}{$\begin{array}{l}\text { Prostate-specific } \\
\text { antigen (PSA) }\end{array}$} & \multicolumn{2}{|c|}{$\begin{array}{l}\text { Ultrasound study } \\
\text { (US) }\end{array}$} & \multirow{2}{*}{$\begin{array}{l}\text { PSA + US } \\
\text { TURP + B }\end{array}$} \\
\hline & B & TURP + B & B & TURP + B & \\
\hline Sensitivity, $\%$ & 95 & 87 & 96 & 87 & 92 \\
\hline Specificity, \% & 33 & 62 & 40 & 66 & 71 \\
\hline Positive predictive value, $\%$ & 39 & 48 & 43 & 51 & 64 \\
\hline Negative predictive value, $\%$ & 94 & 92 & 95 & 92 & 94 \\
\hline Accuracy, \% & 52 & 69 & 58 & 72 & 79 \\
\hline
\end{tabular}

cluded a second or "staging" TURP. Recently, Epstein and associates ${ }^{12}$ reported that $18(86 \%)$ of 21 of their younger patients with stage A1 disease who were treated by radical prostatectomy had residual tumor. Another concern is whether TURP can cause dissemination of local disease. ${ }^{13,14}$ Because of these issues, it may be prudent to diagnose occult stage $\mathrm{A}$ adenocarcinoma of the prostate before performing simple prostatectomy so that a more definitive treatment plan may be substituted.

Also, if $\mathrm{McNeal}^{15}$ is correct that only cancers attaining a critical volume of $1 \mathrm{~mL}$ or 9 $\mathrm{mm}$ in diameter are clinically significant and since ultrasonography can usually only detect lesions larger than 9 to $10 \mathrm{~mm}$ in diameter, perhaps only those clinically significant cancers worthy of treatment would be detected. Currently, the only method other than ultrasonography that seems reasonable to use for searching for occult prostate cancer is serum PSA determination. Although neither procedure can be advocated as all-sufficient for the early diagnosis of prostate cancer, it may be postulated that a combination of both studies can detect a majority of early, unsuspected cancers before simple prostatectomy.

Because Lee and associates ${ }^{16}$ have demonstrated that most cancers of the prostate are hypoechoic, we used this criterion in our search for occult prostate cancer. In our series, 21 out of 30 cancers did indeed appear as hy- poechoic. The remainder were either of mixed (5) echogenicity or isoechoic (4). However, we had 25 ultrasonograms that showed no abnormality, in which cases no cancer was detected on biopsy or TURP. This finding accounts for the difference in specificities noted by Lee and coworkers ${ }^{4}$ and those noted by us. Table $7 \mathrm{di}$ rectly compares their data with ours.

It is difficult to account for the major disparity between specificities (94\% vs $40 \%$ ) other than to state that performance of transrectal ultrasonography is operator-dependent and judgment on areas of altered echogenicity may vary between observers. This view has been shared by Gluck and coauthors, ${ }^{17}$ who thereby accounted for the $40 \%$ specificity with ultrasonographic examination in their patients. Because of the discrepancy in specificities, we believed that combining results of ultrasonography with a more objective value (PSA) could generate a greater accuracy in detecting nonpalpable prostate cancer. As noted in Table 6, we were able to gain modest improvement in our accuracy and positive predictive value by using the combination of tests.

Also, the specificities for PSA and ultrasonography were greatly improved by reviewing all tissue (TURP as well as biopsy specimen) rather than biopsy alone. In a recent study of 1035 men with PSA and transrectal ultrasonography used as a screen for occult prostate cancer, Cooner and associates ${ }^{10}$ reported 
a $35.2 \%$ chance of having adenocarcinoma of the prostate with an abnormal finding on ultrasonography and elevated PSA. Positive predictive values were lower when either PSA determination or ultrasonography was used alone: $18.2 \%$ and $19.6 \%$, respectively. These data, however, did not include pathologic abnormalities on prostatectomy specimens because no patients with negative findings on biopsy or an ultrasonographic study showing no abnormality had a TURP performed. If they did, we can only speculate that their reported values might have been higher.

In our series, we were able to improve our positive predictive value by $13 \%$ with a combination of tests rather than ultrasonography alone ( $64 \%$ vs $51 \%$ ) as judged by final pathologic study. We similarly observed a $16 \%$ improvement in positive predictive value by combining the PSA determinations and ultrasonography results rather than using PSA values alone ( $64 \%$ vs $48 \%$ ).

The major problem with PSA determinations in our study occurred in cases where the ultrasonographic finding was considered normal but the PSA level was elevated. No discrete region in the prostate can be targeted for biopsy; therefore, random biopsy was performed from each side of the gland. Overall, 28 PSA values were elevated when no cancer was detectable on biopsy or TURP. The highest PSA value for benign disease was $53.8 \mathrm{ng} /$ mL noted with a 110 -g TURP specimen.

In a fairly recent report, Agatstein and colleagues ${ }^{18}$ have advocated the routine use of needle aspiration of the prostate to detect stage A cancer. They found that the technique was simple and without complications. It was of greater value in detecting stage $A 2$ versus $A 1$ cancer. However, rather than subject every man to biopsy before TURP, we recommend biopsy for patients at greater risk of having carcinoma (elevated PSA value or abnormality on ultrasonogram). In our patients, we used prophylactic antibiotics as well as the Biopty gun, which resulted in minimal patient discomfort and no significant complications. This technique also provides a better sample of tissue for pathologic examination rather than cytologic study alone.

\section{Table 7}

Comparison of Sensitivity, Specificity, and

Predictive Values for Ultrasound Study for

Lee and Associates ${ }^{4}$ and Fiorelli and Colleagues

\begin{tabular}{|ccc|}
\hline Value & $\begin{array}{c}\text { Lee and } \\
\text { associates } \\
(\mathbf{n}=\mathbf{7 8 4})\end{array}$ & $\begin{array}{c}\text { Fiorelli and } \\
\text { colleagues }_{(\mathbf{n}=\mathbf{1 0 3})}\end{array}$ \\
\hline Sensitivity, \% & 91 & 96 \\
Specificity, \% & 94 & 40 \\
$\begin{array}{c}\text { Positive predictive } \\
\text { value, \% }\end{array}$ & 31 & 43 \\
$\begin{array}{c}\text { Negative predictive } \\
\text { value, \% }\end{array}$ & 100 & 95 \\
\hline
\end{tabular}

As previously stated, we were unable to find any direct relationship beween the PSA values, stages of disease, and Gleason scores. However, we use PSA values posttreatment to monitor response to therapy or progression of disease. Stamey and coauthors ${ }^{7,8,19}$ documented these advantages in their reviews of patients treated by radical prostatectomy, radiation therapy, and orchiectomy.

A final issue is whether it is prudent to evaluate all men and detect early-stage prostate cancer. Although a majority of men with adenocarcinoma of the prostate usually die of other causes, younger men may die of metastatic cancer. ${ }^{10}$ Until we are able to predict the exact biologic activity of certain subsets of tumor cells, can we choose to ignore occult malignancies, especially in younger, healthy men? Now that we have developed transrectal ultrasonography and discovered PSA, how do we use them?

\section{Conclusion}

With the foregoing difficult questions in mind and in keeping with the data we have presented, we believe that transrectal ultrasonography and PSA determinations should not be used as a generalized screen for men older than 40 years. However, both studies should be conducted on patients before prostatectomy for supposedly benign disease.

Most patients who are medical candidates for TURP are capable of undergoing treatment for localized prostate cancer if it is diagnosed. 
Therefore, patients at high risk of having carcinoma (elevated PSA level or abnormality on ultrasonogram [or both]) should then routinely undergo biopsy as no major complications have occurred to date. In so doing, a more definitive treatment plan can be formulated in patients with carcinoma, a few of whom may even be spared simple prostatectomy. However, until more experience is gained in ultrasonographic interpretation and perhaps more refined limits on PSA values predictive of carcinoma, there will still be a certain percentage of unnecessary biopsies performed and even a few missed carcinomas. The likelihood of having prostate cancer with normal results on the ultrasonogram and normal PSA values would seem to be very low, as evidenced by our series ( 2 of 34 patients).

Supported in part by a grant from the Burroughs Wellcome Corporation and AOA Bureau of Research grant No. F-89-01.

1. Silverberg E, Lubera JA: Cancer statistics, 1989. $C A$ 1989;39:3-20.

2. Denton SE, Choy SH, Valk WL: Occult prostatic carcinoma diagnosed by the step-section technique of the surgical specimen. J Urol 1965;93:296-298.

3. Lee F, Littrup PJ, Kumasaka GH, et al: The use of transrectal ultrasound in the diagnosis, guided biopsy, staging and screening of prostate cancer. RadioGraphics 1987;7:627-644.

4. Lee F, Littrup PJ, Torp-Pederson ST, et al: Prostate cancer: Comparison of transrectal US and digital rectal examination for screening. Radiology 1988;168:389-394.

5. Rifkin MD, Friedland GW, Shortliffe L: Prostatic evaluation by transrectal endosonography: Detection of carcinoma. Radiology 1986;158:85-90.

6. Fugino A, Scardino PT: Transrectal ultrasonography for prostate cancer: Its value in staging and monitoring the re- sponse to radiotherapy and chemotherapy. J Urol 1985;133:806810.

7. Stamey TA, Kabalin JN, McNeal JE, et al: Prostate specific antigen in the diagnosis and treatment of adenocarcinoma of the prostate. II. Radical prostatectomy treated patients. J Urol 1989;141:1076-1083.

8. Stamey TA, Kabalin JN, Ferrari M: Prostate specific antigen in the diagnosis and treatment of adenocarcinoma of the prostate. III. Radiation treated patients. J Urol 1989;141:10841087.

9. Cooner WH, Mosley BR, Rutherford CL, et al: Clinical application of transrectal ultrasonography and prostate specific antigen in the search for prostate cancer. J Urol 1988;139:758761 .

10. Cooner WH, Mosley BR, Rutherford CL Jr, et al: Coordination of ultrasonography and prostate-specific antigen in the diagnosis of nonpalpable prostate cancer. $J$ Endourology 1989;3:193-199.

11. Catalona WJ: Staging, in Prostate cancer. Orlando, Fla, Grune \& Stratton, Inc, 1984, pp 57-83.

12. Epstein JI, Oesterling JE, Walsh PC: The volume and anatomical location of residual tumor in radical prostatectomy specimens removed for stage A1 prostate cancer. J Urol 1988;139:975979.

13. Hanks GE, Leibel S, Kramer S: The dissemination of cancer by transurethral resection of locally advanced prostate cancer. J Urol 1983;129:309-311.

14. Meacham RB, Scardino PT, Hoffman GS, et al: The risk of distant metastases after transurethral resection of the prostate versus needle biopsy in patients with localized prostate cancer. J Urol 1989;142:320-325.

15. McNeal JE, Bostwick DG, Kindrachuk RA, et al: Patterns of progression in prostate cancer. Lancet 1986;1:60-63.

16. Lee F, Gray JM, McLeary RD, et al: Transrectal ultrasound in the diagnosis of prostate cancer: Location, echogenicity, histopathology, and staging. Prostate 1985;7:117-129.

17. Gluck R, Cohen M, Warner R: Transrectal ultrasound in early detection of clinical stage A prostate cancer. Urology $1989 ; 34: 58-61$.

18. Agatstein EH, Hernandez FJ, Layfield LJ, et al: Use of fine needle aspiration for detection of stage A prostatic carcinoma before transurethral resection of the prostate: A clinical trial. J Urol 1987;138:551-553.

19. Stamey TA, Kabalin JN, Ferrari M, et al: Prostate specific antigen in the diagnosis and treatment of adenocarcinoma of the prostate. IV. Anti-androgen treated patients. $J$ Urol 1989;141:1088-1090. 
Patients taking

antihistamines may have

impaired performance

without feeling drowsy ${ }^{1,2}$

\section{HUMAN PERFORMANCE}

\section{DEMANDSAN ANTIHISTAMINE PROVEN TO} FREE PATIENTS FROM IMPAIRED PERFORMANCE ${ }^{2.25}$

Impairment-free relief from the first dose through the season

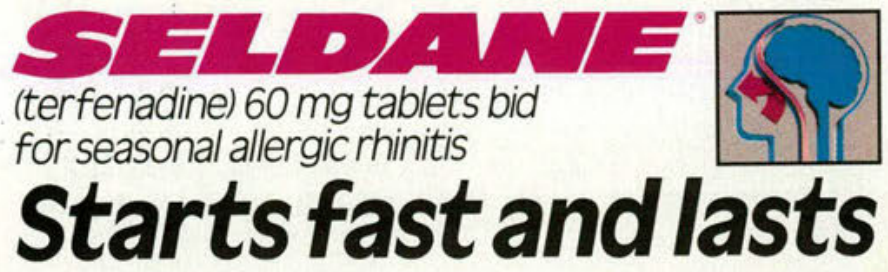




\section{COONTIVE PERFORMANCE}

DEMANDS AN

ANTIHISTAMINE

PROVEN

TOHAVE

NO EFFECTS ON

COGNITIVE

EFFICIENCY AND

ATTENTION SPAN

GREATER THAN

PLACEBO

Impairment-free relief

from the first dose through the season




MOTOR PERFORMANCE

DEMANDSAN

ANTIHISTAMINE

PROVEN

TOHAVE

NO EFFECTS ON

REACTION TIME

AND MOTOR

COORDINATION

GREATER THAN

PLACEBO

Lack of performance impairment must be proven through extensive objective testing-distinct from subjectively reported drowsiness. 24.25 More than 60 objective tests of cognitive, motor, and integrated performancedocumented in over 20 published studies-show that Seldane has no effects on human performance greater than placebo?.22 
SELDANE

FREES PATIENTS

FROM

PERFORMANCE

IMPAIRMENT

CAUSEDBY

CLASSICAL

ANTIHISTAMINES,

WHILE IT

PROVIDES FAST,

STRONG RELIEF

- Effects on patient

performance no greater

than placebo

- Lets patients stay alert

- Strong through-theseason relief

- Convenient 24-hour relief at recommended dosage

- Proven worldwide with more than 100 million patient-months of use
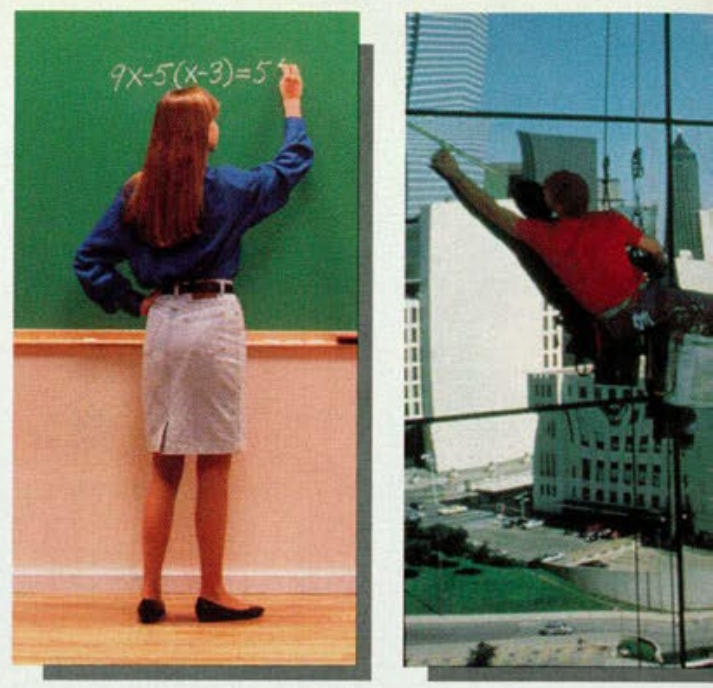

Seldane ${ }^{\oplus}$

(tertenadine) $60 \mathrm{mg}$ Tablets

BRIEF SUMMARY

DESCRIPTION

Seldane (terfenadine) is wailable as tablets for oral administration. Each dents corn starch, gelatin, lactose, magnesium stearate, and sodin bicarbonate.

Seldane is indicated for the relief of symptoms associated with seasona allergic ininitis such as st

The Seldane is contraindicated in patients with a known hypersensitivity to PRECAUTIONS

General: Tertenadine undergoes extensive metabolism in the liver. Patients with impared hepatic function (alcoholic cirrhosis, hepartitis), or on prolongation (e.g thy pokalemia, congenital of syndrome) may experience OT prolongation and or ventriciuar tachycardia a t the recommentided dose The eftect of terfenadine in patients who are recteving agents which alter
the OT Interval is not known. These events have also occurred in patients the or interval is not known. These events have also occurted in patients
on macrolide antibiotics, including erythromycin, but causality is unclear The events may berelated to altered metabolism of the drug. to electrolyte intormation for patients: Patients taking Selidane should receive the follow. inginfiormatorand allergic symptoms. Pinctis should be questisned about prepnancy or pregnancy or lactation onty if the potential benefifi justifies the potential risk to fetus or baby. Patients should be instructed to take Seltane only as needed to store this medication in a tightly closed contsinet in a cool, dry place, rect sunlight, and away from chida

Dug Interactions: Preliminary evidence exists that concurrent wetocon. zole or macrolide administration significantly alters the metabolism of erfenadine. Concurrent use of Seldane winhetoconazicie or troleandomy. cin is not recommended-

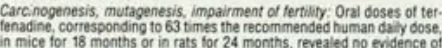
iumorigenicity. Microbial and micronucleus test assays with tertenadine have

Reproduction and fentility studies in rats showed noeffects on male or female erfility at oral doses of up to 21 times the human daily dose. At 63 times

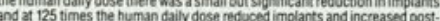
maternal toxicit.

Pregnancy Category C. There was no evidence of animal teratogenicity Reproduction studies have been pertormed in rats at doses 63 times and gain and survival when tertenadine was administered throughour pregnancy and lactation. There are no adequate and well-controlled studies in pregnant women. Seldane should be used during pregnancy only if the
potential benefit justifies the potential risk to the fetus. Vonteratogenic efffects: Seldane is not recommended for nursing women The drug has causeds secreased pup weignt gainand survival in rats gen ind lactation. Effects on pups exposed to Seldane only during lactation are not known. and there are ho adequate and well-controlled studies in women

Acodatric use- Satety and eftectiveness of Seldane in children below the age ADVERSE REACTIONS

Experience from clinical studies, including both controlled and uncontrolled
studies involving more than 2,400 patients who received Seldane, provides in a smal number of parients, the dose was as low as 20 mg twice or as high as 600 mo daily. controlled clinical studies using the recommended dose of $60 \mathrm{mg} \mathrm{bio}$ the incidence of reported adverse effects in patients receiving Seldane was
similar to that reported in patients receiving placebo. (See Table beliow ADVERSE EVENTS REPORTED IN CUNICAL TRIALS

\begin{tabular}{|c|c|c|c|c|c|}
\hline \multirow[b]{2}{*}{$\begin{array}{l}\text { Asvernt } \\
\text { Event }\end{array}$} & \multicolumn{5}{|c|}{ Percent of Palients Reporting } \\
\hline & \multicolumn{3}{|c|}{ 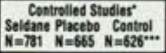 } & \multicolumn{2}{|c|}{ 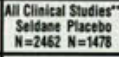 } \\
\hline Central Kenous System & & & & & \\
\hline $\begin{array}{l}\text { Drousiness } \\
\text { Headache }\end{array}$ & $\begin{array}{l}9.0 \\
6.3\end{array}$ & $\begin{array}{l}8.1 \\
7.4\end{array}$ & $\begin{array}{c}18.1 \\
3.8\end{array}$ & $\begin{array}{r}8.5 \\
15.8\end{array}$ & $\begin{array}{r}82 \\
11.2\end{array}$ \\
\hline fatigue & 29 & 0.9 & 5.8 & 45 & 3.0 \\
\hline Daziness & 1.4 & 1.1 & 1.0 & 1.5 & 12 \\
\hline Nenousness & 09 & 02 & 0.6 & 17 & 1.0 \\
\hline Weakness & 09 & 0.6 & 0.2 & 0.6 & 0.5 \\
\hline Appetite increase & 0.6 & 0.0 & 0.0 & 0.5 & 0.0 \\
\hline $\begin{array}{l}\text { Gastrointestinal System } \\
\text { Gastrointesstinal } \\
\text { Distress (Abdominal }\end{array}$ & & & & & \\
\hline $\begin{array}{l}\text { distress, Nausta, } \\
\text { Vomiting. Change in }\end{array}$ & & & & & \\
\hline Bowel hiots) & 4.6 & 30 & 2.7 & 76 & 5.4 \\
\hline $\begin{array}{l}\text { Eye Ear Nose, and Throut } \\
\text { Ory MouthNose/Throut }\end{array}$ & & 18 & 3.5 & & \\
\hline cough & 0.9 & 02 & 0.5 & 2.5 & 1.7 \\
\hline Soce Trom & 0.5 & 0.3 & 0.5 & 3.2 & 16 \\
\hline Epistaxs & 0.0 & 0.8 & 0.2 & 0.7 & 0.4 \\
\hline $\begin{array}{l}\text { Skin } \\
\text { Erupson }\end{array}$ & & & & & \\
\hline and unticer & 10 & 1.7 & 1.4 & 1.6 & 2.0 \\
\hline
\end{tabular}

"Duration of treatment in "CONTROLLED STUDIES" was usually 7-14 DAYS. Ouration of treatment in "ALL CLINICAL STUDIES" was up to 6 months. - CONTROL DRUGS: Chlorpheniramine (291 patients). d-Chlorphenira Rare reports of severe cardiovascular adverse eftects have been received ventricular forlilation), hypotension, palpitations, and syncope. In controlles clinical trials in otherwisenormal, patients with rhinitis, at coses of $60 \mathrm{~m}$ bir. small increases in QTec interval were observed. Changes of the

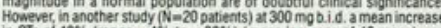
in 0 Tc of $10 \%$ (range $-40 \%$ to $+30 \%$ ) (mean increase of 46 msec) was ets reported in clinical trials (Se: Table), adverse eftects have been reported at a lower incidence in clinica ing as possibly associated with drug administration. These include: alope cia (hair loss or thinning), anaphylaxis, angioedema, bronchospasm. confusion, depression, galactormea, insomnia, menstrval disorders (inclued. ing dysmenorthea), musculoskeletal symptoms, nightmares, paresthesia.
photosensitivity, seizures, sinus tactiycardia, swe ating, tremor, urinary In clinical trials, several instances of mild, or in one case, moderate trans. aminase elevations were seen in patients recenving Seldane. Mid elevations
were also seen in placebo treated patients Marketing experiences include

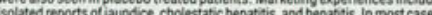
.

OVERDOSAGE

Full Preserioing Information.

DOSAGE AND ADMINISTRATION

One tabiet (60 mg) twice dally for adults and children 12 years and older: MARION MERRELLL DOW INC,

Prescription products Division
Impairment-free relief from the first dose through the season

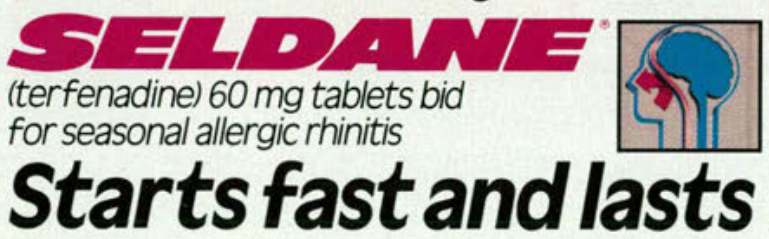

SELXD546
Printed in USA
References: 1. Seidel WF Cohen S Bliwise NG et al. Ann Allergy 1987.590il.58-62 2 Clarke CH, Nich AN. Br J Clin Pharmacol 1978.6:31.35.3. Swire FMM Marsden CA Barber C, et al. Psychopharmacolog 1989.98425-429.4. Nicholson AN Stone BM. Eur J Clin Pharmacol 1983:25:563-566. 5. Nicholson AN, BM. Br J Clin Pharmacol 1982,13.199-202. 6. Nicholson AN, Smith PA, Spencer MB Br J Clin Pharmaco 1982,14.683-690. 7. Reinberg A, Levi , Guillet P, et al Eur J Clin Pharmacol 1978,14:245-252. 8. Moser JE et al J Allergy Clin Immunol 1989:84:316.322 10. Weiner M Arzneim.Forsch/Drug Res 1982:32010 119511 Meador K I I ring DW Thompson EF, et al J Allergy Clin Immunol 1989.84.322.325.12. Aso Sakai Y Jpn J Clin Pharmacol Ther 1988,19(4)681-688. 13. Luscombe DK. Nicholls P.J, Parish PA Pharma peutica 1983:3:370-375 14. Gaillard AWK, Gruisen A de Jong R. Eur J Clin Pharmacol, 1988,35:249-2 15. Moskowitz H, Burns M. Cutis 1988,42:1418. 16. Cohen AF, Hamilton MJ, Peck AW. Eur J Clin Pharm 1987:32:279-288. 17. Roehrs TA. Tietz El, Zorick FJ, et al. Sleep 1984,7(2),137-141, 18. Fink M, irwin P. Ph 20. OHanlon J F Cutis 1988:42:10-13. 21. Kulshrestha VK, Gupta PP. Turner P et al Br J Clin Pharmacol 1978,6-25-29. 22. Nicholson AN Stone BM. Eur J Clin Pharmacol 1986:30-27.32 23. Data on file. Mario Merrell Dow inc, Kansas City, MO 64114 24. Broadbent DE. Br J Clin Pharmacol. 1984,18.55.9S 25. Hindmarch L. Br J Clin Pharmacol. 1980,10.189-209. 